Кропивницький В.С., докторант ННВЦ НУЦЗУ, м. Харків, ORCID: 0000-0002-3527-7283

Kropyvnytskyi V., doctoral student of the Educational, Research and Production center, National University of Civil Protection of Ukraine, Kharkiv

\title{
СУЧАСНИЙ СТАН ТА ЕФЕКТИВНІСТЬ СИСТЕМИ ПУБЛІЧНОГО УПРАВЛІННЯ ТА АДМІНІСТРУВАННЯ У СФЕРІ ЦИВІЛЬНОГО ЗАХИСТУ НА РЕГІОНАЛЬНОМУ РІВНІ
}

\section{CURRENT STATE AND EFFICIENCY OF THE SYSTEM OF PUBLIC GOVERNANCE AND ADMINISTRATION IN THE SPHERE OF CIVIL PROTECTION AT THE REGIONAL LEVEL}

У статті визначено рівень захисту населення, територій, навколишнього природного середовища від надзвичайних ситуачій на регіональному рівні. Здійснено оцінку ефективності системи публічного управління та адміністрування у сфері ичивільного захисту. Розглянуто основні напрямки підвищення ефективності системи публічного управління та адміністрування у сфері иивільного захисту на регіональному рівні в сучасних умовах.

Ключові слова: публічне управління та адміністрування, ичивільний захист, надзвичайні ситуації, Кодекс циввільного захисту України, механізми публічного управління та адміністрування у сфері цчивільного захисту.

The article defines the level of protection of the population, territories, environment from emergencies at the regional level. The effectiveness of the system of public governance and administration in the sphere of civil protection has been assessed. The main directions of increasing the efficiency of the system of public governance and administration in the sphere of civil protection at the regional level in modern conditions are considered.

Key words: public administration and administration, civil protection, emergencies, the Code of Civil Protection of Ukraine, mechanisms of public administration and administration in the field of civil protection.

Постановка проблеми. Захист населення, територій, навколишнього природного середовища та майна від надзвичайних ситуацій, а також захист життя й здоров'я громадян України від небезпечних наслідків аварій і катастроф техногенного, екологічного, природного й військового характеру є однією з важливих функцій держави, яка формує сутність та зміст цивільного захисту.

Аналіз останніх досліджень і публікацій. Дослідженню питань сучас320 
ного стану та оцінки ефективності системи публічного управління та адміністрування у сфері цивільного захисту на регіональному рівні присвятили свої публікації такі вчені, як Андреєв С., Ковальчук В., Майстро С., Труш О. та інші.

Однак чимало питань стосовно напрямків підвищення ефективності системи публічного управління та адміністрування у сфері цивільного захисту на регіональному рівні в сучасних умовах залишаються недостатньо дослідженими.

Метою статті є визначення сучасного стану та оцінка ефективності системи публічного управління та адміністрування у сфері цивільного захисту на регіональному рівні.

Виклад основного матеріалу. Кожен громадянин України має право на захист свого життя і здоров'я від наслідків аварій, катастроф, пожеж, стихійного лиха та на вимогу гарантій забезпечення реалізації цього права від органів державної влади [1].

А належна реалізація вказаної функції цивільного захисту органами державної влади можлива лише за умов всебічного забезпечення ефективності функціонування всіх складових системи публічного управління та адміністрування у сфері цивільного захисту, в тому числі на регіональному рівні $[2 ; 3]$.

Центральним органом виконавчої влади, який реалізує державну політику у сфері цивільного захисту, захисту населення і територій від надзвичайних ситуацій та запобігання їх виникненню, ліквідації наслідків надзвичайних ситуацій, рятувальної справи, гасіння пожеж, пожежної та техногенної безпеки, діяльності аварійно-рятувальних служб, а також гідрометеорологічної діяльності є Державна служба України з надзвичайних ситуацій, від ефективності діяльності якої значною мірою залежить рівень цивільного захисту, як на державному, так і на регіональному рівні.

В цілому в регіонах України у 2019 р. було зафіксовано 146 надзвичайних ситуацій (табл. 1).

Внаслідок негоди було зруйновано 1 житловий будинок; пошкоджено 19 багатоповерхових житлових будинків (м. Калуш); підтоплено та пошкоджено 1 тис. 320 приватних житлових будинків, 53 соціальних закладів; зруйновано та пошкоджено 278 господарських будівель; затоплено понад 6,3 тис. присадибних ділянок; пошкоджено 1950 га сільськогосподарських угідь; розмито 27,34 км берегів; зруйновано та пошкоджено 350,44 км автомобільних доріг, 48 автомобільних мостів, 13,7 км берегоукріплень, 8,13 км дамб, 60 пішохідних мостових переходів; пошкоджено водопровід у м. Калуші. Під час паводка загинула одна особа. Сума коштів, необхідних для ліквідації наслідків надзвичайної ситуації, становить понад 420 млн. грн.

В Закарпатській області, внаслідок значних опадів (рясних дощів та граду) 20-25 травня 2019 р. відбулися різкі підйоми рівнів основних річок та сталося затоплення понад 3 тис. га сільськогосподарських угідь, 687 домо- 
господарств, 112 житлових будинків; пошкодження 13,8 км берегоукріплень, 39 мостових переходів (з них 19 пішохідних), 79,1 км дорожнього покриття, 462 м підпірних стінок тощо. Під час паводка загинула одна дитина. За попередньою оцінкою сума коштів, необхідних для ліквідації наслідків надзвичайної ситуації, становить понад 600 млн. грн.

Таблиця 1

Надзвичайні ситуації (НС) в регіонах України, 2010-2019 pp. [5]

\begin{tabular}{|c|c|c|c|c|c|c|c|c|c|c|c|}
\hline Регіони / роки & 2010 & 2011 & 2012 & 2013 & 2014 & 2015 & 2016 & 2017 & 2018 & 2019 & $\begin{array}{c}\text { Всього } \\
\text { НС за } \\
\text { період }\end{array}$ \\
\hline АР Крим & 12 & 4 & 18 & 3 & 1 & & & & & & 38 \\
\hline Вінницька & 9 & 7 & 6 & 3 & 6 & 5 & 4 & 7 & 3 & 4 & 54 \\
\hline Волинська & 4 & 7 & 1 & 8 & 6 & 6 & 10 & 5 & 6 & 7 & 60 \\
\hline Дніпропетровська & 17 & 10 & 5 & 3 & 6 & 5 & 8 & 4 & 9 & 9 & 76 \\
\hline Донецька & 35 & 29 & 25 & 20 & 20 & 7 & 6 & 24 & 10 & 10 & 186 \\
\hline Житомирська & 8 & 6 & 10 & 3 & 5 & 5 & 8 & 5 & 5 & 8 & 63 \\
\hline Закарпатська & 9 & 5 & 5 & 7 & 4 & 5 & 6 & 9 & 8 & 7 & 65 \\
\hline Запорізька & 10 & 11 & 8 & 4 & 7 & 5 & 1 & 3 & 4 & 3 & 56 \\
\hline Івано-Франківська & 8 & 4 & 3 & 3 & 2 & 3 & 5 & 7 & 2 & 7 & 44 \\
\hline Київська & 9 & 7 & 13 & 4 & 3 & 13 & 5 & 6 & 6 & 7 & 73 \\
\hline Кіровоградська & 3 & 3 & 3 & 2 & 2 & 2 & 6 & 3 & 3 & 4 & 31 \\
\hline Луганська & 26 & 18 & 13 & 11 & 7 & 3 & 4 & 5 & 9 & 7 & 103 \\
\hline Львівська & 11 & 14 & 20 & 14 & 7 & 4 & 6 & 3 & 5 & 8 & 92 \\
\hline Миколаївська & 9 & 12 & 11 & 7 & 7 & 7 & 10 & 8 & 8 & 5 & 84 \\
\hline Одеська & 14 & 17 & 13 & 10 & 9 & 7 & 14 & 13 & 5 & 11 & 113 \\
\hline Полтавська & 3 & 2 & 3 & 5 & 5 & 8 & 10 & 5 & 4 & 10 & 55 \\
\hline Рівненська & 5 & 11 & 4 & 3 & 5 & 4 & 6 & 10 & 2 & 5 & 55 \\
\hline Сумська & 5 & 4 & 5 & 6 & 4 & 7 & 7 & 3 & 5 & 5 & 51 \\
\hline Тернопільська & 3 & 9 & 8 & 3 & 7 & 5 & 2 & 3 & 6 & 4 & 50 \\
\hline Харківська & 14 & 11 & 11 & 8 & 10 & 9 & 6 & 10 & 4 & 3 & 86 \\
\hline Херсонська & 19 & 6 & 15 & 4 & 10 & 4 & 5 & 9 & 7 & 4 & 83 \\
\hline Хмельницька & 11 & 6 & 6 & 4 & 5 & 4 & 4 & 2 & 3 & 2 & 47 \\
\hline Черкаська & 4 & 4 & 9 & 4 & 2 & 5 & 3 & 9 & 5 & 1 & 46 \\
\hline Чернівецька & 11 & 1 & 2 & 2 & 1 & 4 & 7 & 5 & 2 & 5 & 40 \\
\hline Чернігівська & 7 & 7 & 6 & 5 & 8 & 9 & 8 & 3 & 5 & 5 & 63 \\
\hline м. Київ & 4 & 4 & 9 & 8 & 3 & 14 & 7 & 12 & 7 & 5 & 63 \\
\hline м. Севастополь & 3 & 1 & 1 & 1 & 1 & & & & & & 7 \\
\hline За межами України & 0 & 1 & 0 & 0 & 0 & 0 & 0 & 0 & 0 & 0 & 1 \\
\hline Всього НС & 254 & 221 & 212 & 144 & 143 & 148 & 149 & 166 & 126 & 146 & 1711 \\
\hline
\end{tabular}


В Одеській області 10 червня 2019 р. внаслідок пожежі в одноповерховому корпусі відділення № 7 комунального некомерційного підприємства «Одеський обласний медичний центр психічного здоров'я» (м. Одеса) загинуло 7 та 3 особи постраждало, а 17 серпня 2019 р. внаслідок пожежі у двоповерховому готелі «Токіо Стар» (м. Одеса) загинуло 9 та постраждало 10 осіб. Під час ліквідації пожежі евакуйовано 136 осіб.

У Львівській області 28 серпня 2019 р. внаслідок руйнування конструктивних елементів одного під'їзду чотириповерхового житлового будинку (м. Дрогобич) загинуло 8 (3 них 1 дитина) та 14 осіб постраждало (3 них 10 дітей); упродовж 19-20 листопада 2019 року під час проведення робіт із запуску теплопостачання у містах Новий Розділ та Новояворівськ виникли пошкодження магістральних теплових мереж (пориви), в результаті чого без теплопостачання залишилося 233 будинки, в яких проживає понад 38 тис. осіб, у тому числі м. Новий Розділ - 171 будинок (26,2 тис. осіб) та м. Новояворівськ - 62 будинки (12,1 тис. осіб).

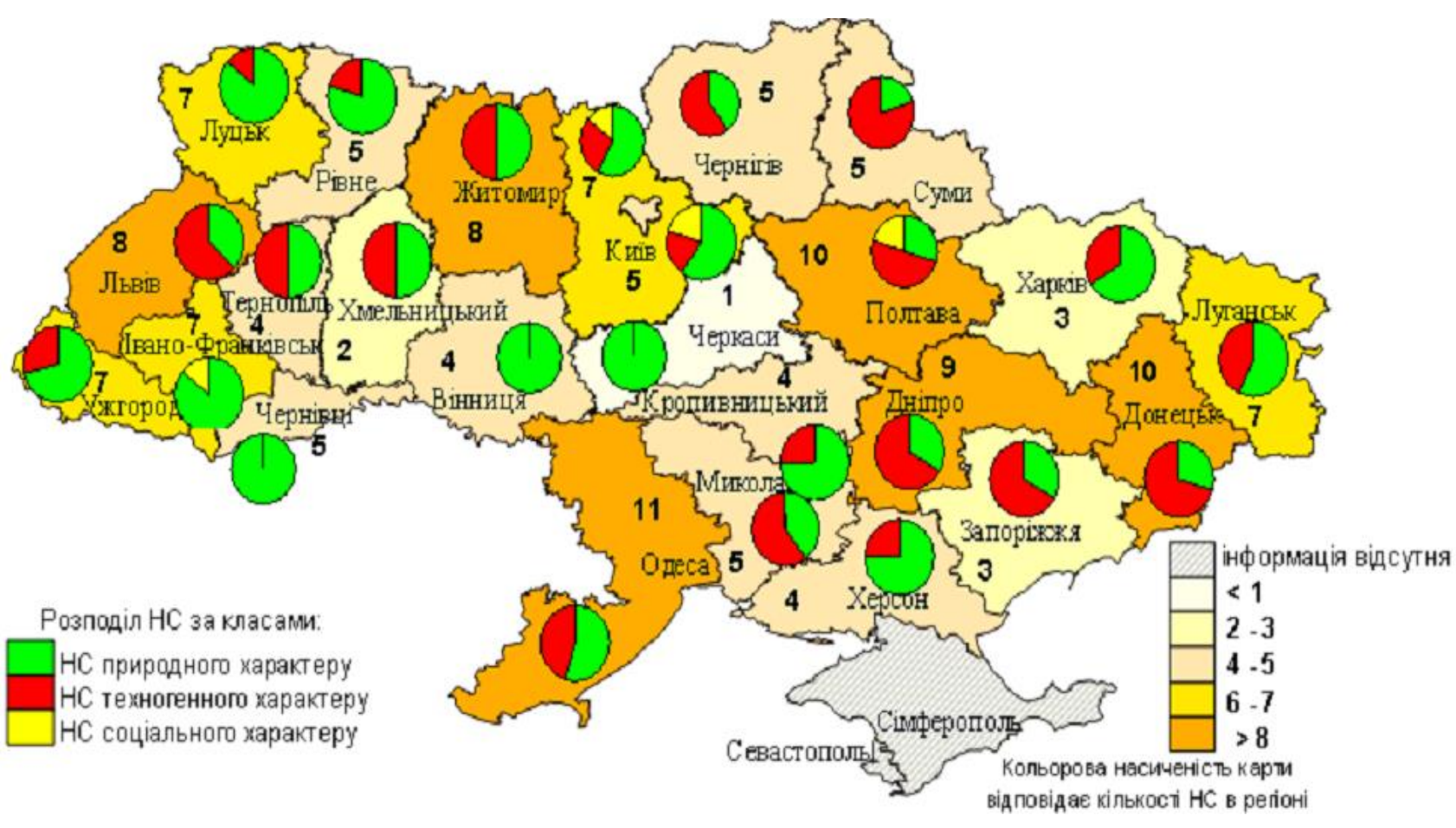

Рис. 1. Розподіл кількості надзвичайних ситуацій за класами по регіонах України, 2019 р. [5].

Розподіл кількості надзвичайних ситуацій за класами (техногенного, природного, соціального характеру) та їх розподіл регіонами України у 2019 рр. наведено на рис. 1, а у порівнянні з 2018 р. - в табл. 2. 
Таблиця 2

Розподіл кількості НС за класами та регіонами України, 2018-2019 pp. [5]

\begin{tabular}{|c|c|c|c|c|c|c|c|c|}
\hline \multirow{3}{*}{ Регіони } & \multicolumn{8}{|c|}{ Надзвичайні ситуації } \\
\hline & \multicolumn{2}{|c|}{$\begin{array}{c}\text { Техногенного } \\
\text { характеру }\end{array}$} & \multicolumn{2}{|c|}{$\begin{array}{c}\text { Природного ха- } \\
\text { рактеру }\end{array}$} & \multicolumn{2}{|c|}{$\begin{array}{c}\text { Соціального } \\
\text { характеру }\end{array}$} & \multicolumn{2}{|c|}{ Всього } \\
\hline & 2018 & 2019 & 2018 & 2019 & 2018 & 2019 & 2018 & 2019 \\
\hline Вінницька & 1 & 0 & 2 & 4 & 0 & 0 & 3 & 4 \\
\hline Волинська & 1 & 1 & 5 & 6 & 0 & 0 & 6 & 7 \\
\hline $\begin{array}{l}\text { Дніпро- } \\
\text { петровська }\end{array}$ & 6 & 6 & 3 & 3 & 0 & 0 & 9 & 9 \\
\hline Донецька & 8 & 7 & 2 & 3 & 0 & 0 & 10 & 10 \\
\hline Житомирська & 3 & 4 & 2 & 4 & 0 & 0 & 5 & 8 \\
\hline Закарпатська & 2 & 2 & 6 & 5 & 0 & 0 & 8 & 7 \\
\hline Запорізька & 2 & 2 & 2 & 1 & 0 & 0 & 4 & 3 \\
\hline $\begin{array}{l}\text { Івано- } \\
\text { Франківська }\end{array}$ & 0 & 0 & 2 & 6 & 0 & 1 & 2 & 7 \\
\hline Київська & 4 & 2 & 2 & 4 & 0 & 1 & 6 & 7 \\
\hline Кіровоградська & 2 & 1 & 1 & 3 & 0 & 0 & 3 & 4 \\
\hline Луганська & 0 & 3 & 9 & 4 & 0 & 0 & 9 & 7 \\
\hline Львівська & 3 & 5 & 2 & 3 & 0 & 0 & 5 & 8 \\
\hline Миколаївська & 4 & 3 & 4 & 2 & 0 & 0 & 8 & 5 \\
\hline Одеська & 0 & 5 & 5 & 6 & 0 & 0 & 5 & 11 \\
\hline Полтавська & 2 & 5 & 2 & 3 & 0 & 2 & 4 & 10 \\
\hline Рівненська & 0 & 1 & 2 & 4 & 0 & 0 & 2 & 5 \\
\hline Сумська & 3 & 4 & 2 & 1 & 0 & 0 & 5 & 5 \\
\hline Тернопільська & 2 & 2 & 4 & 2 & 0 & 0 & 6 & 4 \\
\hline Харківська & 3 & 1 & 1 & 2 & 0 & 0 & 4 & 3 \\
\hline Херсонська & 3 & 1 & 4 & 3 & 0 & 0 & 7 & 4 \\
\hline Хмельницька & 0 & 1 & 3 & 1 & 0 & 0 & 3 & 2 \\
\hline Черкаська & 3 & 0 & 2 & 1 & 0 & 0 & 5 & 1 \\
\hline Чернівецька & 0 & 0 & 2 & 5 & 0 & 0 & 2 & 5 \\
\hline Чернігівська & 1 & 3 & 3 & 2 & 1 & 0 & 5 & 5 \\
\hline м. Київ & 0 & 1 & 5 & 3 & 2 & 1 & 7 & 5 \\
\hline
\end{tabular}


Найбільшу кількість загиблих у НС зареєстровано у Одеській області (46 осіб, переважна більшість 3 яких (36 осіб) загинули внаслідок НС, пов'язаних із пожежами).

Більшість постраждалих у НС зареєстровано у м. Києві (495 осіб, усі внаслідок медико-біологічних НС, пов'язаних із захворюванням людей на кір, сальмонельоз та гострі кишкові інфекції).

Надзвичайні ситуації державного рівня зареєстровано: у червні 2019 р. - пов'язана із загрозою припинення роботи технологічного обладнання об'єктів магістрального трубопровідного транспорту газотранспортної системи України у зв'язку із відсутністю достатніх обсягів природного газу для технологічних потреб АТ «Укртрансгаз»; у грудні 2019 р. - пов'язана із пожежею у 6-ти поверховій будівлі Одеського коледжу економіки, права та готельно-ресторанного бізнесу (м. Одеса), внаслідок якої загинуло 16 осіб (з них 1 дитина) та 30 осіб (з них 16 дітей) постраждало, підрозділами ДСНС врятовано та евакуйовано 40 осіб.

Упродовж 2019 р. в населених пунктах та на об'єктах суб'єктів господарювання в регіонах України зафіксовано 95 тис. 915 пожеж, що на $22 \%$ більше порівняно з 2018 р. Внаслідок пожеж загинуло 1 тис. 902 людини (у тому числі 58 дітей) та 1 тис. 519 людей отримали травми (3 них 135 дітей). Порівняно з 2018 р. кількість загиблих унаслідок пожеж зменшилася на 3,3 \%, кількість травмованих збільшилась на 0,2 \% (рис. 2).

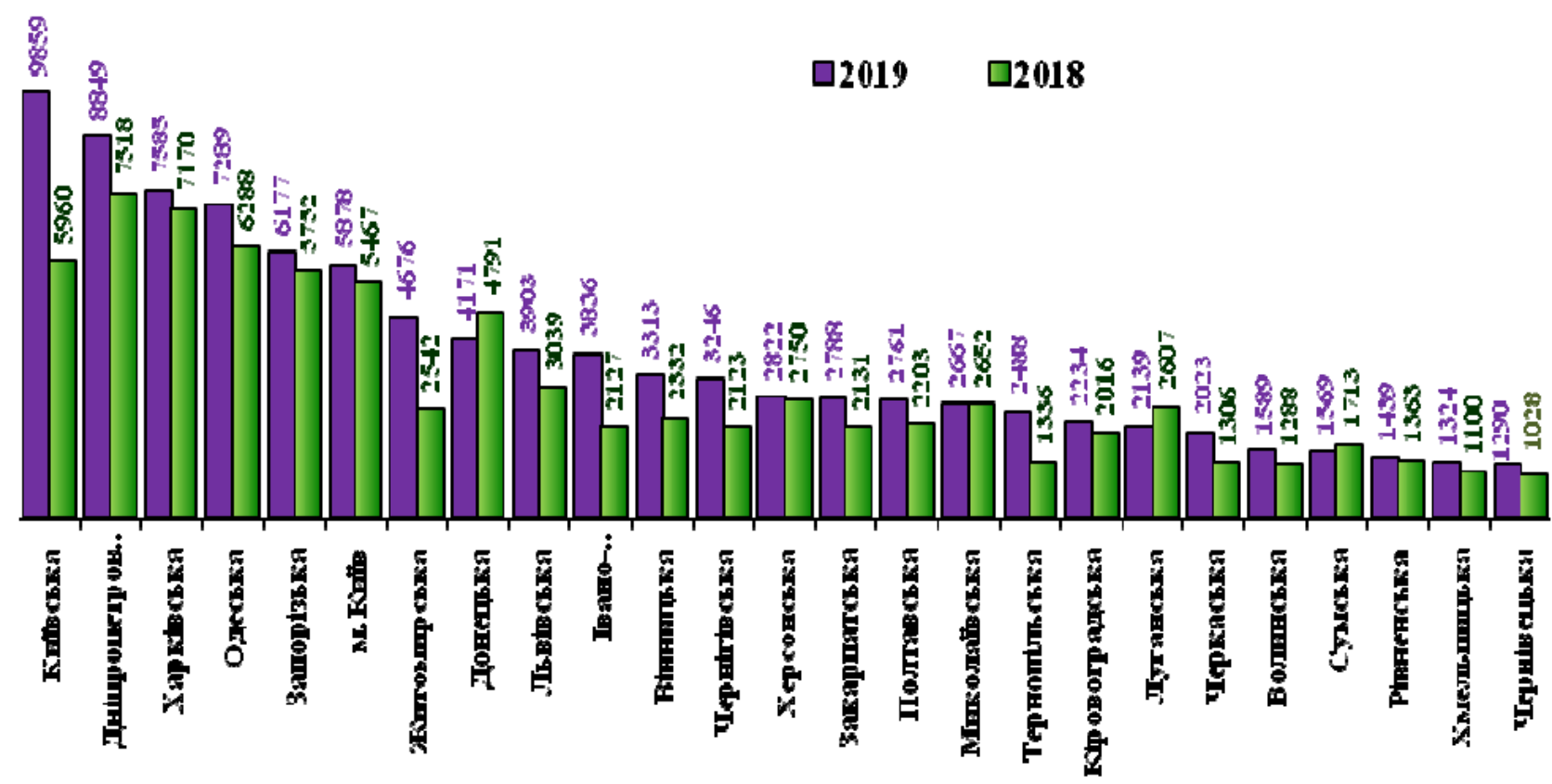

Рис. 2. Абсолютні показники кількості пожеж по регіонах України, 2018-2019 pp. [5]. 
У житловому секторі виникло 30 тис. 582 пожежі, що на 3,4 \% менше ніж у 2018 p. (2018 p. - 31 тис. 674 пожежі).

У виробничій сфері виникло 588 пожеж, що на $7 \%$ менше ніж у 2018 р. (2018 рік - 632 пожежі).

На транспорті виникла 4 тис. 451 пожежа, що на 2,4 \% більше ніж у 2018 p. (2018 p. -4 тис. 345 пожеж).

У природних екосистемах у 2019 р. зафіксовано збільшення кількості пожеж майже у 2 рази (2019 р. - 38 тис. 497 пожеж, 2018 р. - 21 тис. 152 пожежі), а площа, пройдена вогнем, збільшилася майже у 3 рази (2019 р. - 35 тис. 831 га, 2018 р. - 12 тис. 466 га).

Найбільша їх кількість виникла у Київській (5 тис. 632 пожежі, 5 тис. 86 га), Дніпропетровській (4 тис. 618 пожеж, 3 тис. 332 га), Харківській (3 тис. 445 пожеж, 1 тис. 221 га, Одеській (3 тис. 442 пожежі, 2 тис. 88 га) та Запорізькій (3 тис. 234 пожежі, 1 тис. 165 га) областях.

У лісовому фонді зафіксовано збільшення кількості пожеж на 5,4 \% (2019 p. - 1 тис. 307 пожеж, 2018 p. - 1 тис. 258 пожеж), а загальна площа пожеж на 2,7 \% (2019 p. - 1 тис. 393 га, 2018 р. - 1 тис. 322 га). Найбільша кількість лісових пожеж виникла у Херсонській (162 пожежі, 168 га), Київській (141 пожежа, 203 га) та Дніпропетровській (122 пожежі, 90 га) областях.

На торфовищах кількість пожеж порівняно з минулим роком збільшилась у 2,3 рази (2019 р. - 529 пожеж, 2018 р. - 225 пожеж), а площа, пройдена вогнем, майже у 2,2 рази (2019 p. - 524 га, 2018 р. - 233 га).

Найбільша кількість торф'яних пожеж виникла у Київській (172 пожежі, 70 га) та Львівській (128 пожеж, 42 га) областях.

На сільськогосподарських угіддях кількість пожеж збільшилася майже у 4 рази (2019 p. - 357 пожеж, 2018 р. - 92 пожежі), а площа, пройдена вогнем - у 2,4 рази (2019 р. - 1 тис. 572 га, 2018 рік - 650 га). Найбільша кількість пожеж виникла у Дніпропетровській (71 пожежа, 183 га) та Київській (42 пожежі, 189 га) областях.

На відкритих ділянках місцевості (трава, сміття, тощо) кількість пожеж збільшилася майже у 2 рази (2019 р. - 36 тис. 304 пожежі, 2018 р. - 19 тис. 577 пожеж), а площа, пройдена вогнем, майже у 2,6 рази (2019 р. - 32 тис. 340 га, 2018 р. - 12 тис. 466 га). Найбільша кількість пожеж виникла у Київській (5 тис. 277 пожеж, 4 тис. 624 га), Дніпропетровській (4 тис. 425 пожеж, 3 тис. 58 га), Одеській (3 тис. 418 пожеж, 1 тис. 988 га) та Харківській (3 тис. 339 пожеж, 1 тис. 56 га) областях.

Унаслідок пожеж на території України у 2019 р. загинуло 1 тис. 902 особи, що на 3,3 \% або на 65 осіб менше ніж у 2018 р. Середній по Україні показник загибелі людей на 100 тис. населення становить - 4,5. Найгірші показники загиблих зареєстровано у Чернігівській $(7,7)$, Київській $(7,6)$ та 
Запорізькій $(6,4)$ областях.

Ефективне запобігання НC та ліквідація їх наслідків вимагають підвищення кваліфікації пожежних і рятувальників та удосконалення організаційних заходів проведення пожежно-рятувальних операції.

Так, протягом 2019 р. ДСНС України на регіональному рівні було організовано та проведено:

- $\quad$ спеціальне навчання щодо демонстрації можливостей пожежнорятувальних сил під час проведення операцій з ліквідації наслідків надзвичайних ситуацій на базі полігона Мобільного рятувального центру швидкого реагування (1 серпня, Київська обл., Обухівський р-н, с. П'ятихатки);

- $\quad$ навчання в рамках переатестації пошуково-рятувальної команди важкого класу Мобільного рятувального центру швидкого реагування ДСНС у системі Міжнародної консультативної групи OOH - INSARAG. (5 вересня, Київська область, Обухівський р-н, с. П'ятихатки);

- $\quad$ тактико-спеціальні навчання щодо організації взаємодії та координації дій органів системи МВС під час спільного виконання завдань на тему: «Комплексне застосування наземних та авіаційних сил ДСНС під час рятувальних операцій, ліквідації наслідків надзвичайних ситуацій та гасіння пожеж» на базі Міжнародного міжвідомчого центру підготовки підрозділів Національної гвардії (30 вересня, Київська обл., Бориспільський р-н, с. Стаpe);

- $\quad$ командно-штабні навчання (КШН) з питань організації реагування органів управління та сил цивільного захисту на загрози осінньозимового періоду із залученням керівного складу МВС, ДСНС, Мінрегіону, Мінекоенерго, Мінсоцполітики, МО3, Мінінфраструктури, Укравтодору, Укртрансбезпеки, Нацполіції та обласних і Київської міської держадміністрацій. Під час КШН практично відпрацьовано питання організації управління під час ліквідації наслідків надзвичайних ситуацій, пов'язаних із порушенням функціонування транспортної інфраструктури, систем житловокомунального господарства внаслідок погіршення погодних умов, надання допомоги соціально незахищеним верствам населення та розгортання мережі пунктів обігріву у складних умовах осінньо-зимового періоду [5].

Висновки. Таким чином, сучасна система публічного управління та адміністрування у сфері цивільного захисту в Україні на регіональному рівні $є$ недосконалою та не повною мірою забезпечує виконання покладених на неї функцій та завдань. Отже потребують невідкладного удосконалення існуючі механізми публічного управління та адміністрування у сфері цивільного захисту на регіональному рівні, що сприятиме зниженню ризику виникнення надзвичайних ситуацій, а також сприятиме підвищенню ефективності та результативності системи публічного управління та адміністрування у сфері цивільного захисту, у тому числі в умовах європейської інтеграції Ук- 
раїни, що й буде предметом подальших наукових досліджень.

\section{Список використаних джерел:}

1. Конституція України // ВВР України. 1996. № 30. С. 381-418.

2. Андреєв С. О. Державні системи цивільного захисту: інституціональні засади та проблеми розвитку: монографія / С. О. Андреєв ; Нац. акад. держ. упр. при Президентові України. Харків : Тім Пабліш Груп, 2017. 432 c.

3. Майстро С.В. Нормативно-правовий механізм державного управління системою цивільного захисту в Україні / С.В. Майстро, О.О. Труш // Актуальні проблеми державного управління: зб. наук. пр. Х.: Вид-во ХарРІ НАДУ „Магістр”, 2014. № 2 (46). С. 210 - 218.

4. Кодекс цивільного захисту України від 02.10.2012. № 5403-VI [Текст] // Офіційний вісник України. 2012. № 89. Ст. 3589.

5. Звіт про основні результати діяльності Державної служби України з надзвичайних ситуацій у 2019 році. URL: https://www.kmu.gov.ua/ storage/ app/sites/1/17-civik-2018/zvit_2019/zvit-2019-dsns.pdf.

\section{References:}

1. Constitution of Ukraine. [Konstitucia Ukraini ]. BPR of Ukraine. (1996): No. 30. 381-418. [in Ukrainian].

2. Andreev, S. State Civil Protection Systems: Institutional Principles and Developmental Problems. [Dergavni systemy civil nogo zahystu: institucional'ni zasady ta problemy rozvytku]. Kharkiv: Tim Publ. Grup, 2017. [in Ukrainian].

3. Maystro, S., Trush, O. Regulatory and Legal Mechanism of Public Administration of the Civil Protection System in Ukraine. [Normativno-pravoviy mehanizm derzhavnogo upravlinnya systemoyu civil'nogo zahistu v Ukraini]. Current problems of public administration 2 (46) (2014): 210-218. [in Ukrainian].

4. Code of Civil Protection of Ukraine. [Kodex civil'nogo zahistu Ukraini]. dated 02.10.2012. № 5403VI [Text]. Official Ukrainian Visnyk. (2012): No. 89. 3589. [in Ukrainian].

5. Report on the main results of the Civil Service of Ukraine for Emergencies in 2019. [Zvit pro osnovni rezul'taty diyal'nosti Derzhavnoyi sluzhby Ukrayiny z nadzvychaynykh sytuatsiy u 2019 rotsi]. (n.d.). kmu.gov.ua. Retrieved from: https://www.kmu.gov.ua/ storage/app/sites/1/17-civik-2018/zvit_2019/ zvit2019-dsns.pdf. [in Ukrainian]. 